\title{
WORKING WITH SOCIALLY MALADJUSTED YOUTH AND CHILDREN WITH DEVELOPMENTAL DISORDERS. PREDICTORS AND CORRELATIONS OF HEALTH AMONG PERSONNEL IN YOUTH CENTRES
}

\author{
JUSTYNA SZRAJDA
}

Department of Hygiene, Epidemiology and Ergonomics, Collegium Medicum in Bydgoszcz, Nicolaus Copernicus University in Torun, ul. Curie-Skłodowskiej 9, Bydgoszcz, Poland E-mail address: politykazdrowotna@op.pl ORCID: 0000-0002-4698-520X

\section{EWA SYGIT-KOWALKOWSKA}

2.Institute of Psychology, Department of Organizational and Management Psychology, Kazimierz Wielki University in Bydgoszcz ul. Staffa 1, Bydgoszcz, Poland

E-mail address: ewasygit@gmail.com ORCID: 0000-0001-5909-5516

\section{MAGDALENA WEBER-RAJEK}

Department of Physiotherapy, Division of Basic Physiotherapy,

Collegium Medicum in Bydgoszcz, Nicolaus Copernicus University in Torun, ul. Techników 3, Bydgoszcz, Poland

E-mail address: magdawr69@gmail.com ORCID: 0000-0002-3938-1571

\section{MALWINA TUDOROWSKA}

Daily Psychiatric Ward, Gizińscy Medical Center ul. Leśna 9A, Bydgoszcz, Poland

E-mail address: malwina.tudorowska@gmail.com ORCID: 0000-0002-7056-7120

\section{MARCIN ZIÓŁKOWSKI}

Department of Preventive Nursing, Division of Psychiatric Nursing, Collegium Medicum in Bydgoszcz, Nicolaus Copernicus University in Torun, ul. Łukasiewicza 1, Bydgoszcz, Poland

E-mail address: marcin_ziolkowski@interia.pl ORCID: 0000-0001-7707-7290 


\author{
ALINA BORKOWSKA \\ Department of Clinical Neuropsychology, \\ Collegium Medicum in Bydgoszcz, Nicolaus Copernicus University in Torun, \\ ul. M. Curie Skłodowskiej 9, Bydgoszcz, Poland \\ E-mail address: alab@cm.umk.pl \\ ORCID: 0000-0001-7305-0242
}

\begin{abstract}
Aim. The aim of the study was to evaluate mental and physical well-being, as well as their correlates and predictors in a group of employees working at youth educational centres and sociotherapy centres.

Methods. A total of 96 employees working at youth educational centres and sociotherapy centres took part in the study. The following psychometric tools were used: the Psychosocial Working Conditions Questionnaire, the Mini-COPE, the LOT-R, and the GSES.

Results. The results obtained indicate that people working in helping professions experience mental and physical health problems. Only $3 \%$ of the subjects declared they sleep all night. Over $40 \%$ and over $35 \%$ of the subjects estimate they suffer from low mood and irritation episodes, respectively, rather frequently or continually. Subjects with poorer mental health are more likely to use Helplessness, Avoidance behaviour, or Turning to religion to cope with stress. The strongest predictor of mental well-being is the sense of self-efficacy, whereas, the strongest predictor of physical well-being is the ability to cope with stress by giving in to the feeling of Helplessness.

Conclusions. The study demonstrated poor mental and physical well-being of the subjects. A statistically significant correlation was found between sex and the level of mental and physical health. Employees working at youth educational centres and sociotherapy centres with better mental and physical well-being had a stronger sense of self-efficacy and a higher level of life optimism.
\end{abstract}

Key words: teachers, job stress, mental health.

\title{
INTRODUCTION
}

F acilities which educate and also rehabilitate children and youth are the centrepiece of the education system. Hence, employees who work at youth educational centres (MOW; pol. Młodzieżowy Ośrodek Wychowawczy) and sociotherapy centres (MOS; pol. Młodzieżowy Ośrodek Socjoterapii) face a difficult working environment. Mariusz Granosik, Anita Gulczyńska and Renata Szczepanik (2015) stated that in a generalised professional profile of an educator/ teacher who attempts to rehabilitate and be a socio-therapist, which is created in everyday communication, they appear as someone in control, someone with discipline and who executes the realisation of tasks, someone who is a therapist and who re-educates (p. 17). The aim of youth educational centres is to elimi- 
nate the causes and symptoms of social maladjustment of the youth and prepare them to comply with current social and legal standards. Youth sociotherapy centres are designated for children and youth who due to developmental and social functioning disorders and learning difficulties require their education and work, as well as sociotherapy methods used, to be individually-adjusted. The most common causes for placing young people (aged 13-18) in such institutions include: evading compulsory education, signs of demoralisation (use of alcohol, intoxicating substances, and prostitution), aggressive and violent behaviour towards their peers and environment, suicide attempts, running away from home, personality disorders, belonging to an organised criminal group, or committing criminal offences (robbery, vandalism, theft, battery).

Children and youth referred to sociotherapy facilities have a particular profile and display certain symptoms of demoralisation, which are confirmed by opinions of pedagogues and psychologists ordered by consultative bodies or court advisories (Szczepanik, 2008). Such children are disobedient, impulsive, arrogant and focus on immediate needs. According to their psychological profile, they show disregard for authority and tendency to lie.

Looking at the statistics carried out in 31 European countries, the education sector is one of the most stressful working environments, as respondents in this sector declared greater mental strain that those in other work sectors (ParentThirion, Fernández-Macías, Hurley, \& Vermeylen, 2007). Therefore, it can be assumed that in addition to the traditional stresses for teachers, the staff in such centres are burdened with additional qualification requirements which are difficult to meet. Teachers and educators working at such centres belong to helping professions. They are required to work for the well-being of others, show commitment, and establish emotional contact. Occupational load may contribute to mental and physical health problems in people working in helping professions. Due to the particular nature of youth-teacher interactions staff are exposed to occupational stress (Bowers, 2004; Briner, Poppleton, Owens, \& Kiefer, 2008; Kirkcaldy, \& Shephard, 2001; Kyriacou, \& Sutcliffe, 1977). At the same time, the teachers' educational success depends on their ability to cope with stress (Ratliff, 1988).

To a substantial extent, the ability to cope with stress factors depends on psychological resources. Personal traits that have a positive effect on health include: self-acceptance, sense of authorship, sense of control, sense of self-efficacy, ability to effectively solve tasks and influence one's environment, intelligence and flexibility, thoughtfulness and emotional competences, as well as optimism in life (Antoniou, Ploumpi, \& Ntalla, 2013; Chow, \& Ho 2012; Grant, \& Kinman, 2015).

\section{AIMS OF THE STUDY AND RESEARCH QUESTIONS}

The aim of the study was to evaluate mental and physical well-being (interchangeably referred to as 'mental health' and 'physical health' in this paper), 
as well as their correlates and predictors in a group of employees working at youth educational centres and sociotherapy centres.

The following study questions were asked:

1. What is the level of mental and physical well-being of the subjects?

2. What is the correlation between the level of the mental and physical well-being, age, job tenure, and sex in the studied group?

3. What is the correlation between the level of mental and physical wellbeing and personal resources, such as sense of self-efficacy, optimism in life, and strategies for coping with stress in the studied group?

4. Which of the studied personal resources is a predictor for mental and physical well-being in the studied group?

The study was based on scientific reports, therefore, we assumed that women will show a lower level of well-being than men, and that dealing with stress, optimism and self-efficacy will be predictors of better health at work. Avoiding behaviour aimed at dealing with stress was a predictor of bad mood.

\section{METHODS}

\section{Setting and participants}

The study subjects were teachers and educators working at youth educational centres and sociotherapy centres in Poland. Research surveys were left in the study room for employees.

The surveys came complete with the description and purpose of the study as well as a written request to fill them out and put into a specially prepared "ballot box." The cover letter indicated that the survey is completely anonymous and that the results will be used solely for scientific purposes. 96 subjects ( 24 women and 72 men), aged 26 to 55 years old (mean age was 42 years + SD = 9), and with a job tenure of 1 to 30 years (average job tenure was 11 years; +SD $=6$ ) were enrolled into the study.

\section{Measures}

The following tools were used in the study:

1. The Psychosocial Working Conditions questionnaire (Polish: "Psychospołeczne warunki pracy") developed by Roman Cieślak and Maria Widerszal-Bazyl (2000). The theoretical D scale and two empirical scales (D1 and D2) examining mental and physical well-being were used in the study. The question "What is the level of your well-being?" was the main component of the theoretical scale. The D1 scale included an overall assessment of physical health and stress level at work, as well as somatic symptoms, such as headache, stomach ailments, and heart problems. The mental well-being factor (D2 scale) focused on the evaluation of negative emotional states, life and job satisfaction, and self-confidence at work. The sten scale was used to describe the level of mental and physical well-being of the respondents. Cronbach's a for the D scale was .94 (.86 for the D1 scale and .83 for the D2). 
The presentation of the results includes qualitative analyses of the questions, which are acceptable methods for analysing questionnaire results. The collected quantitative and qualitative data were compared with the results for teachers, such as standard ten scores and response frequencies, included in the tool manual.

2. The Mini-COPE (Coping Inventory) used to measure stress coping abilities. It was developed by Charles S. Carver, and adapted in Poland by Zygfryd Juczyński and Nina Ogińska-Bulik (2009). The tool is used to evaluate strategies applied to cope with stress. A subject responds to each statement using a scale from 0 to 3 , where 0 means "I almost never do it" and 3 means "I almost always do it." The higher the result, the more intense is the use of a selected strategy. The factor score structure employs the following strategies: Active coping, Helplessness, Avoidance behaviour, Searching for support, Turning to religion, Acceptance, and Sense of humour. Cronbach's a for the Mini-COPE scale ranged from .79 to .87 .

3. The LOT-R (Life Orientation Test) developed by Michael F. Scheier, Charles S. Carver, and Michael W. Bridges, and adapted in Poland by Ryszard Poprawa and Juczyński (Juczyński, \& Ogińska-Bulik, 2009). This test is used to evaluate dispositional optimism understood as a personality trait. Optimism, understood in this way, is a generalised positive expectancy for good outcomes. Using a five-grade scale, subjects estimate to what extent a given statement applies to them. Cronbach's a for the entire 6 items of the scale is .78, which suggests that the scale has an acceptable level of internal consistency.

4. The GSES (Generalized Self Efficacy Scale) developed by Ralf Schwarzer, Matthias Jerusalem, and Juczyński (Juczyński, \& Ogińska-Bulik, 2009). The GSES consists of 10 statements which apply to one factor. It measures an individual's level of perceived self-efficacy in coping with difficult situations and obstacles. The GSES is intended to test healthy and ill subjects. Cronbach's alphas ranged from .76 to .90 .

Statistical analyses were conducted using the IBM SPSS Statistics 21 package. The Kolmogorov-Smirnov test was used to determine the normality of data distribution. A correlation between variables was evaluated using the Spearman's rho and Pearson's $r$ coefficients. Linear regression analysis with the stepwise method was also used. We assumed a confidence level of $\mathrm{p}<0.05$.

Firstly, the data was analysed using basic descriptive statistics, and the Kolmogorov-Smirnov test was applied to examine the normality of quantitative variable distribution. It turned out that distribution of most variables deviates from the normal distribution. Nevertheless, the skewness value for these variables exceeds the contractual absolute value of 0.8 only in the case of seniority, and consequently the distribution of other scales is not grossly asymmetrical with respect to the Gauss curve. It was, therefore, decided that parametric tests will be carried out with the participation of other variables.

The research was approved by the Bioethics Committee of Nicolaus Copernicus University, functioning at Collegium Medicum in Bydgoszcz (KB 628/2016). 
A scale was used, where (Stanisz, 1998):

a) $0<$ rxy $\leq 0.1$ is a slender correlation,

b) $0.1 \leq$ rxy $\leq 0.3$ is a weak correlation,

c) $0.3 \leq \mathrm{rxy} \leq 0.5$ is an average correlation,

d) $0.5 \leq \mathrm{rxy} \leq 0.7$ is a high correlation,

e) $0.7 \leq$ rxy $\leq 0.9$ very high correlation.

The article presents results excluding low and weak correlations.

\section{RESULTS}

The mental well-being results were nearly evenly distributed between three categories. 31 subjects demonstrated poor mental health, whereas 29 and 36 subjects showed average and high mental health, respectively. As far as physical well-being was concerned, $33.3 \%$ of the respondents rated it as low, 37.5\% as high, and $29.2 \%$ as average.

According to the procedure described in the Proposal for analysis of questionnaire results chapter in the "Psychosocial work conditions" manual, a percentage of the responses to several questions was used in the analysis. The responses were then compared to the percentage distribution of teachers' responses in the questionnaire manual. The analyses showed that over $40 \%$ and over $35 \%$ of the subjects estimate they suffer from low mood and irritation episodes, respectively, continually or frequently. When it comes to sense of nervousness, over $30 \%$ of the subjects estimate they "continually" or "rather frequently" experience this state. The respondents indicated that they continually had problems collecting their thoughts or concentrating more than nine times as often as the group of teachers. More than six times as many respondents declared they experienced loneliness "rather frequently" compared with teachers' answers presented in the questionnaire manual.

The largest differences between the subjects' results and the standards for teachers were observed with regard to sleep self-evaluation. Nearly half of the subjects selected the answer "I do not sleep at all", which is more than six times as many respondents compared with teachers' answers presented in the manual. Only less than 3\% of the subjects declared that they sleep all night and this result is over sixteen times lower than the official standard. Qualitative analysis also demonstrated that more than five times as many employees working at the centres assessed their health as very bad and quite bad in comparison to the reference group of teachers in the questionnaire manual (38.53\% of the sample vs. $6.9 \%$ of the teachers). The study participants experienced constant headaches and very frequent tightness and/or pain in the chest more than nine times as often as the reference group of teachers in the questionnaire manual. Nearly $35 \%$ of the respondents reported feeling weak "frequently" or "very frequently" (compared to less than $12 \%$ of the standard quoted in the manual).

Using random samples, a correlation between the level of the mental and physical well-being, age, job tenure, sex, place of work, and job position were 
evaluated with the Spearman's rho test and Student's t-test. Correlations between age, job tenure, and the level of mental well-being proved to be statistically insignificant. When it comes to the sex variable, the obtained result proved to be statistically significant $-\mathrm{t}(94)=-2.78 ; \mathrm{p}<0.01 ; 95 \% \mathrm{Cl}[-0.73 ;-0.12]$; $\mathrm{d}=0.664$. As the means indicate, women $(\mathrm{M}=3.34$; $\mathrm{SD}=0.67)$ scored lower in mental well-being than men $(\mathrm{M}=3.86 ; \mathrm{SD}=0.50)$. The relationship between age, job tenure, and physical well-being also turned out to be statistically insignificant $(\mathrm{p}=0.148 ; \mathrm{p}=0.886)$. The data obtained using independent samples and the Student's t-test were statistically significant with respect to the gender variable $\mathrm{t}(62.71)=-3.79 ; \mathrm{p}<0.001 ; 95 \% \mathrm{Cl}[-0.78 ;-0.24] ; \mathrm{d}=0.811$. This means that the level of physical well-being in women is different from that of men. As indicated by the mean scores, women $(\mathrm{M}=3.59$; $\mathrm{SD}=0.79)$ scored lower on this scale than men $(\mathrm{M}=4.10 ; \mathrm{SD}=0.48)$. During the next part of the study we analysed the correlation between the level of mental well-being, physical well-being, sense of self-efficacy, optimism in life, and strategies for coping with stress using the Pearson $r$ method and using the scatter diagrams. Physical well-being is statistically significantly correlated with Helplessness $(r=-0.405 ; \mathrm{p}=0.263)$, Turning to religion $(r=-0.315$; $p=0.002)$, sense of self-efficacy $(r=0.376 ; p<0.001)$, and life optimism $(r=0.346$; $\mathrm{p}=0.001)$. Relationships with Helplessness and Turning to religion are negative, which means that the higher the score for these strategies, the lower the level of respondents' physical well-being (Fig.1, Fig.2.). On the other hand, relationships with the sense of self-efficacy and optimism are positive (Fig.3, Fig.4.).

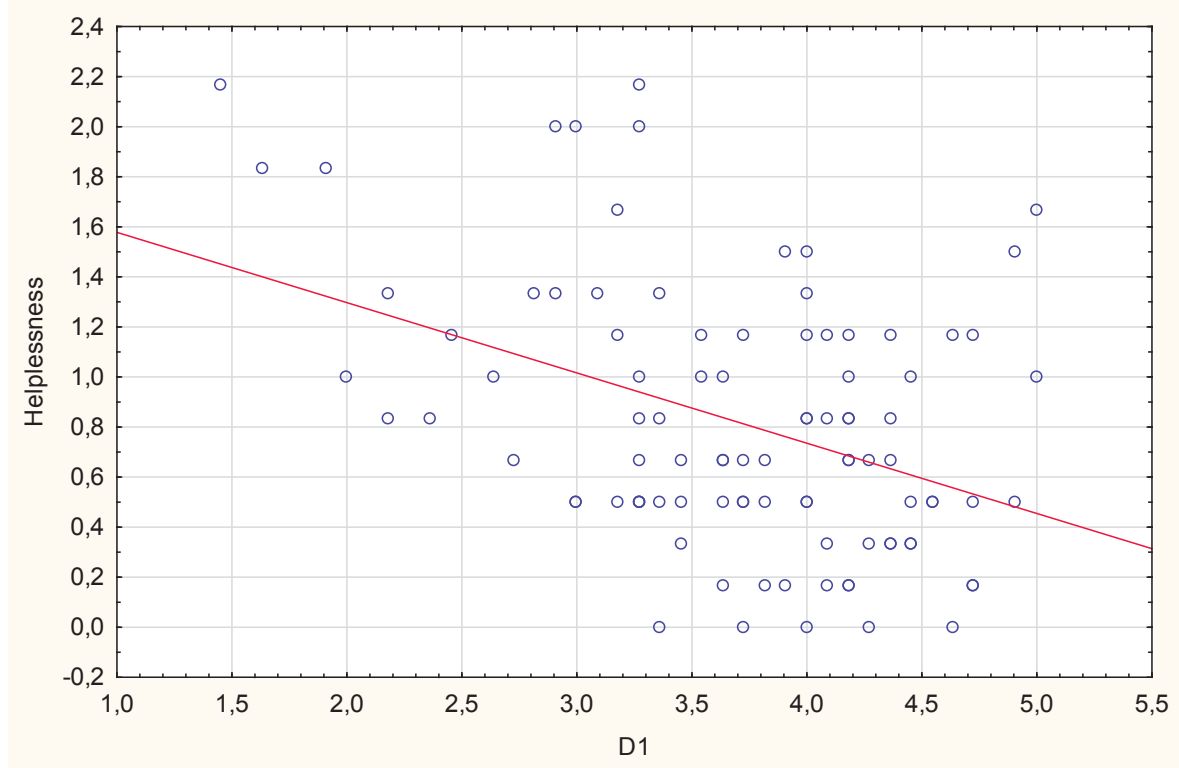

Figure 1. The scatter diagram - Helplessness to physical well-being (D1) for the analyzed group 


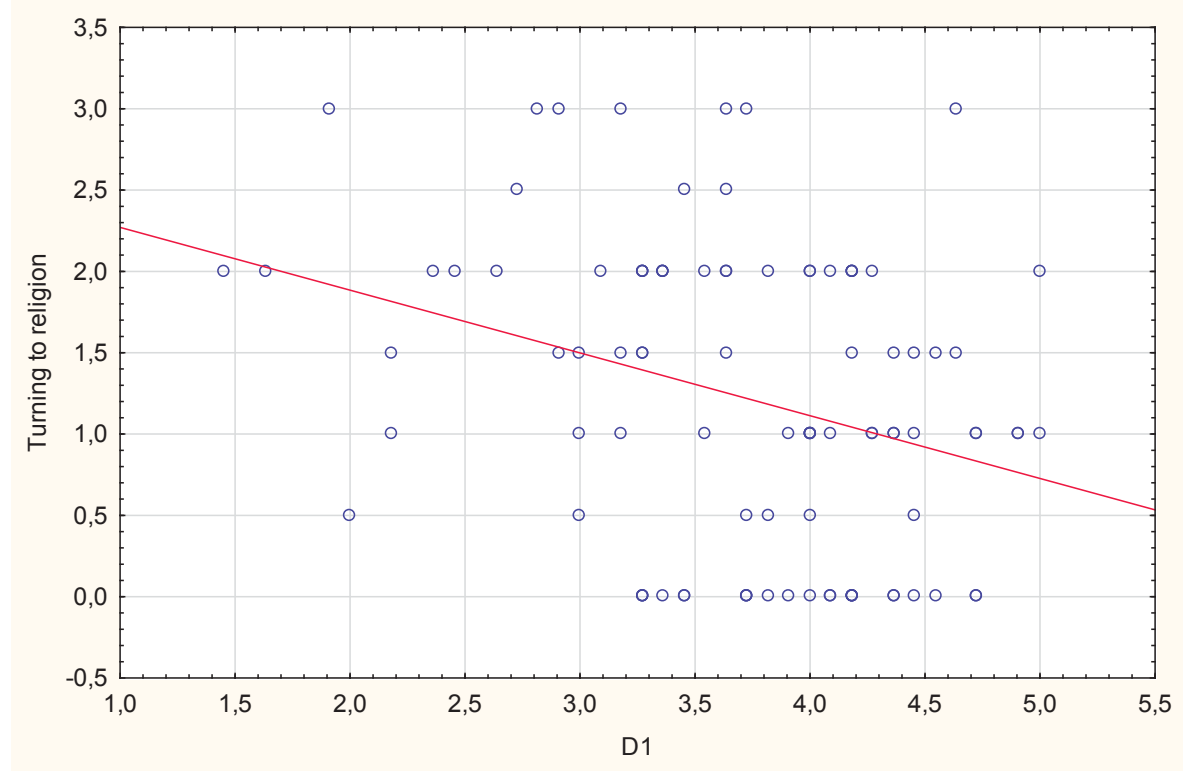

Figure 2. The scatter diagram - Turning to religion to physical well-being (D1) for the analyzed group

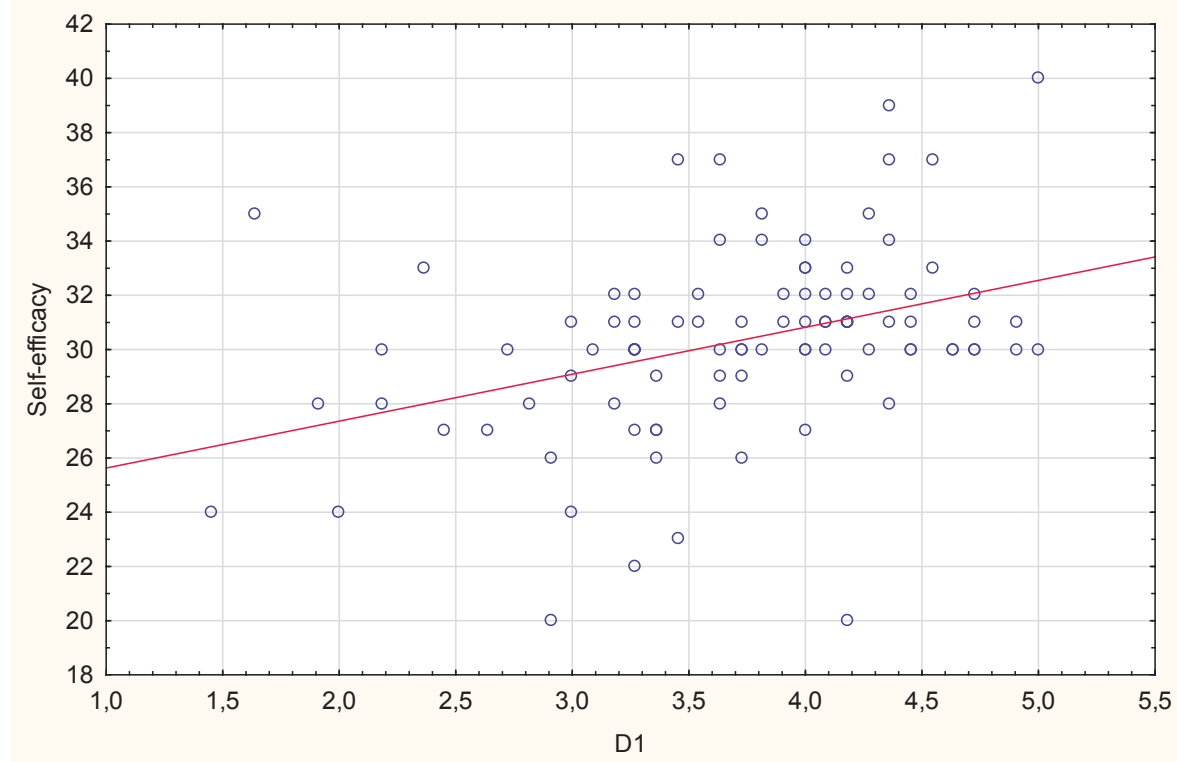

Figure 3. The scatter diagram - Self-efficacy to physical well-being (D1) for the analyzed group 


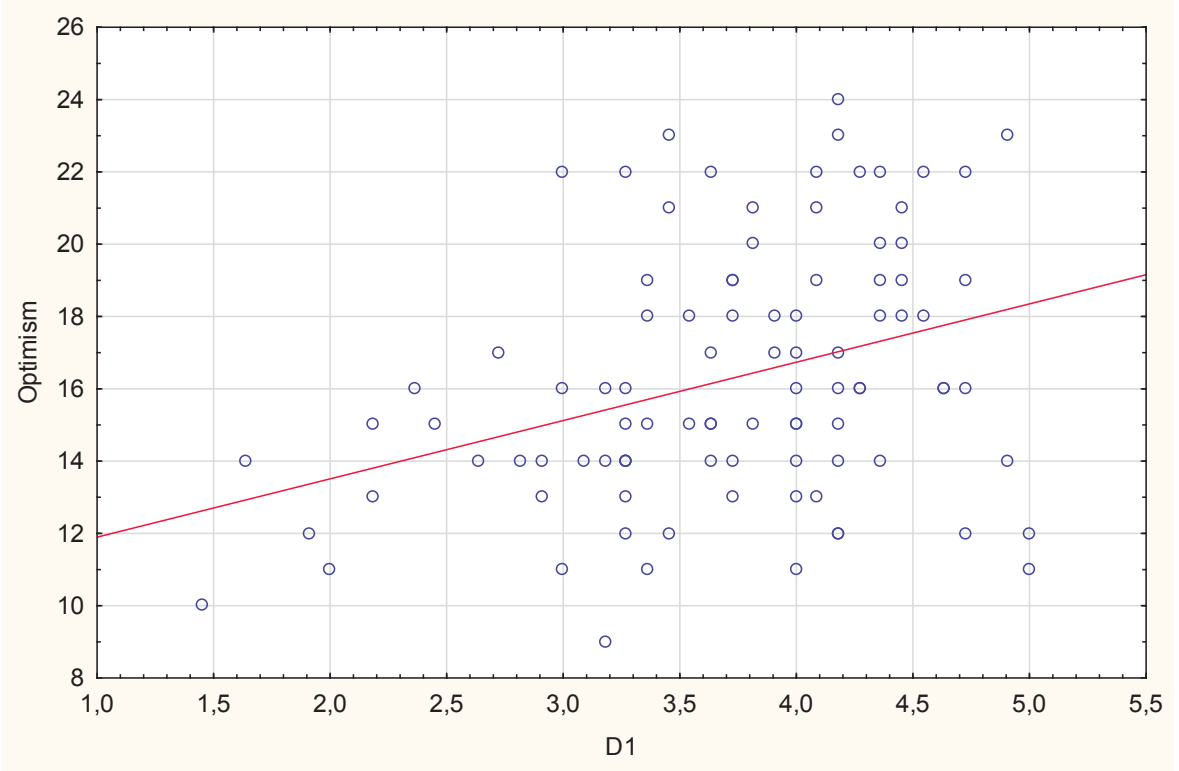

Figure 4. The scatter diagram - Optimism to physical well-being (D1) for the analyzed group

The results showed that the level of mental well-being is statistically significantly correlated with strategies for coping with stress, such as Helplessness, Avoidance behaviour and Turning to religion but these relationships are negative and weak. Furthermore, mental well-being is statistically significantly correlated with the sense of self-efficacy $(r=0.401 ; p=0.001)$. This relationship is positive and moderately strong, which means that the poorer the mental well-being, the lower the sense of self-efficacy (Fig.5).

In the final part of the study, we performed a linear regression analysis with the stepwise method. Mental well-being was the dependent variable in the model. The quantitative variables which significantly correlated with this variable were used as predictors. The results of analysis showed that self-efficacy was the strongest predictor, explaining the highest percentage of variance. The R2 value indicates that about $16.1 \%$ of the variability in mental well-being can be explained by the self-efficacy. Furthermore, adding the Avoidance behaviour to predictors' pool to the model will cause a statistically significant increase in the model efficiency. These two predictors explain $17.9 \%$ of the variability of mental well-being. The results are provided in Table 1. 


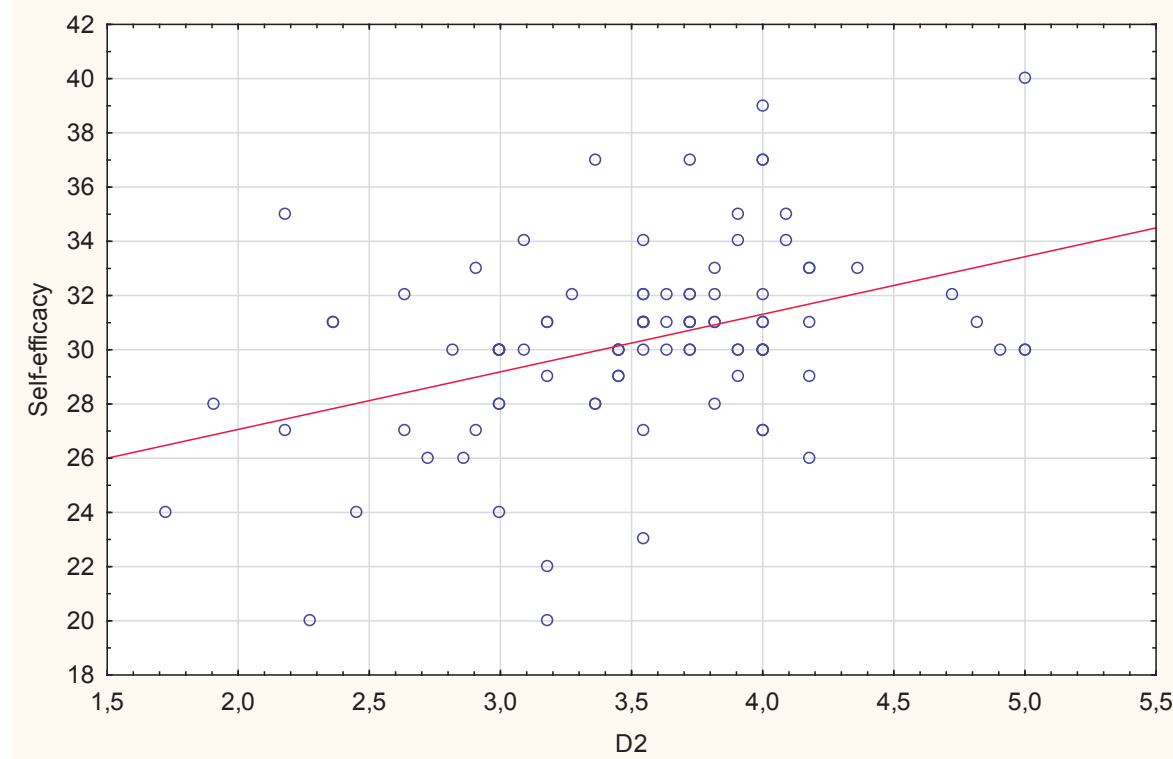

Figure 5. The scatter diagram - Self-efficacy to mental well-being (D2) for the analyzed group

Table 1. Summary of prediction properties of two models for the dependent variable of mental and physical well-being levels

\begin{tabular}{|c|c|c|c|c|c|c|}
\hline \multicolumn{7}{|l|}{ Mental well-being } \\
\hline & B & SE & Beta & $\mathrm{R}^{2}$ & $\Delta \mathrm{R}^{2}$ & F change \\
\hline Model 1 & & & & 0.16 & & $18.02 * *$ \\
\hline (Constant) & 1.24 & 0.55 & & & & \\
\hline Sense of self-efficacy & 0.08 & 0.02 & $0.40^{* *}$ & & & \\
\hline Model 2 & & & & 0.18 & 0.04 & $11.37^{* *}$ \\
\hline (Constant) & 1.76 & 0.60 & & & & \\
\hline Sense of self-efficacy & 0.07 & 0.02 & $0.37^{* *}$ & & & \\
\hline Avoidance & -0.24 & 0.12 & $-0.19^{*}$ & & & \\
\hline \multicolumn{7}{|l|}{ Physical well-being } \\
\hline Model 1 & & & & & 0.16 & $18.41^{* * *}$ \\
\hline (Constant) & 4.19 & 0.13 & & & & \\
\hline Helplessness & -0.58 & 0.14 & $-0.41^{* * *}$ & & & \\
\hline Model 2 & & & & 0.21 & 0.06 & $7.36^{* *}$ \\
\hline (Constant) & 2.33 & 0.7 & & & & \\
\hline Helplessness & -0.45 & 0.14 & $-0.31^{* *}$ & & & \\
\hline Sense of self-efficacy & 0.06 & 0.02 & $0.27^{* *}$ & & & \\
\hline
\end{tabular}

${ }^{*} \mathrm{p}<0.05 ;{ }^{* *} \mathrm{p}<0.01 ;{ }^{* * *} \mathrm{p}<0.001$ 
The results of analysis showed that the Helplessness scale was the strongest predictor, explaining the highest percentage of variance in physical well-being (Tab. 1) allowing to predict $16 \%$ of the physical well-being variance. However, adding a second parameter to the model - the sense of self-efficacy - causes a $21 \%$ increase to overall variance. The unstandardised B coefficient indicates that increase of Helplessness score by one unit results in 0.45 unit decrease in physical well-being score. On the other hand, increase in self-efficacy score by one unit causes a 0.06 unit decrease in physical well-being score.

\section{DISCUSSION}

Due to the restrictive and controlling nature of sociotherapy, employees working at sociotherapy and educational centres need to be competent and have a particular skillset to work with their residents. The relationship between children and the staff in such centres can be full of disappointment and failures. Christina Maslach and Michael P. Leitner (2011) believe that negative emotions are the factor which transforms commitment into professional burnout.

The authors aimed to analyse work conditions of employees working at MOW and MOS centres. The detailed analysis of physical health scores showed that the respondents frequently assessed their health as bad or quite bad, had more headaches, experienced tightness and/or pain in the chest, and more often felt weak and distracted. Steven Seidman and Joanne Zager (1991) had already shown that among teachers, physical ailment symptoms may reflect difficulties in coping with occupational stress and may manifest as pain, depressive disorders, and a tendency to suffer from colds. Somatic symptoms, such as chronic fatigue, migraine headaches, insomnia, and gastric disorders are also typical signs of emotional exhaustion, which may lead to professional burnout (Glise, Ahlborg, \& Jonsdottir, 2014).

The authors believe that the data on sleep patterns of the respondents should be investigated further. The results of this study are consistent with the data on this professional group available in the literature. The study conducted by Cecilia Reece-Peters (2013) among German teachers showed that nearly 30\% of the subjects experienced sleep problems. De Jane C. de Souza et al. (2012) showed that secondary school teachers presented symptoms of partial sleep deprivation and poor quality of sleep. This may contribute to excessive sleepiness during the day, affect employees' health, quality of life, and teaching abilities. Sleep disorders are a very common complication of depression and may be associated with an increased risk of significant depression and suicidal tendencies (Nutt, Wilson, \& Paterson, 2008), whereas sleep disorders caused by chronic stress can contribute to the risk of occupational burnout. At the same time, it was found that increased physical activity and proper sleep hygiene ensure high quality of sleep and may buffer the adverse effects of occupational stress (Flueckiger, Lieb, Meyer, Witthauer, \& Mata, 2016). 
In this study, the sense of self-efficacy proved to be the strongest predictor of mental well-being. The authors proved that the sense of self-efficacy is a measure of predicting educational efficacy and ability to solve pedagogical problems (Korur, 2018; Woolfolk \& Hoy, 1990;). The higher the sense of selfefficacy, the higher the objectives people set for themselves and the stronger is their commitment (Woolfolk, Hoy, \& Davis, 2006). Teachers with a high sense of self-efficacy are more motivated and efficient in their work. A positive image of oneself as an employee, measured through own actions and efficacy, helps to foster a positive perception of one's mental health (Schwarzer, \& Hallum, 2008).

In this study, sex was a diversifying factor for the study group in terms of the mental and physical well-being. Published literature generally supports the idea that indicators for mental disorders are significantly higher in women than men $(33.2 \%$ versus $21.7 \%)$, also when a professional activity variable is considered (55.4\% versus 4.6\%) (Burke, 2003). Higher depression and anxiety indicators in the group of women are associated with work factors, such as high requirements and low decision-making power (Williams et al., 1997). Studies show that women are particularly exposed to occupational stress factors including multiple roles conflict, discrimination, stereotypes, and a lack of career development (Lennon, 1995).

Interestingly, it turned out that work experience, which is another sociodemographic variable, did not influence the mental and physical well-being of examined employees. As other analyses have shown, it can be a significant, positive predictor of job satisfaction in a group of school teachers (Akhtar, Hashmi, \& Naqvi, 2010; Gesinde, \& Adejumo, 2012). People working in helping professions are exposed to stress factors which may affect their mental and physical well-being. Due to the particular nature of sociotherapy and the work environment in sociotherapy centres, teachers and educators are required to adapt and act in a specific way to be effective. The correlation analyses showed that physical well-being at work is linked to the level of optimism in life. This is confirmed by studies on secondary school teachers, which show a negative relationship between the optimism in life and causes of occupational burnout, such as personal commitment and emotional exhaustion (Jenaro, Flores, \& Arias, 2007). Pessimists are more prone to experience physical exhaustion and a lower sense of professional accomplishments.

In this study, $30-40 \%$ of the employees suffered from frequent or continual states of irritation, depression, stress, and nervousness. Such information is key in describing mental strain experienced at work. The study results show that employees who experience emotional tension at work have a greater tendency to objectify interpersonal relationships (Yagil, 2012). This translates into loosening interpersonal relationships and excessive distancing. Rehabilitation efficacy is determined not only by the cooperation factor but also the overall profile of an employee exposed to certain occupational factors. Perhaps children and youths who participated in Anna Karłyk-Ćwik's (2009) study experienced the effects of psychological strain, as they rated their teachers as showing little 
fairness, readiness to show support in tough times, empathy, and kindness and rarely taking their opinion into account.

People who have problems coping with occupational stress are more prone to experience the above-mentioned conditions, such as irritation, anger and depression (Terelak, \& Mystkowski, 2010). On the other hand, the ability to recognise, express, and control one's emotions (i.e., emotional intelligence) influences the ability to cope with stress in helping professions. Also, it may affect the relationship between perceived stress and consequences resulting from certain associated experiences (Durán, \& Extremera, 2004; Morrison, 2007; Seidman, \& Zager, 1991).

The presented study has its limitations. Workplace stresses were not included in the presented results. For example, we did not analyse the following issues which can play a significant role in regulating stress: dealing with discipline, conflicting expectations of teachers, educators and students, and performing tasks under time pressure. The authors of the study did not control any non-work factors, such as other stressful events in a subject's personal life, that could have potentially influenced teachers' and educators' mental well-being.

According to Chris Kyriacou (2001), studies conducted on a group of teachers should focus on the effectiveness of interventional strategies intended to reduce stress level. Occupational burnout and its influence on teachers' and educators' mental and physical well-being are other aspects that should be studied more thoroughly. The available data indicates that this adverse phenomenon may explain the relation between high expectations at work and poor health of people working in helping professions (Hakanen, Bakker, \& Schaufeli, 2006).

\section{BIBLIOGRAPHY}

[1] akhtar, S.N., Hashmi, M.A., \& Naqvi S.I.H. (2010). A comparative study of job satisfaction in public and private school teachers at secondary level. Procedia - Social and Behavioral Sciences, 2, 4222-4228.

[2] Antoniou, A.S., Ploumpi, A., \& Ntalla, M. (2013). Occupational stress and professional burnout in teachers of primary and secondary education: The role of coping strategies. Psychology, 4(3A), 349-355.

[3] Bowers, T. (2004). Stress, teaching and teacher health. Education, 32(3), 73-80.

[4] Briner, R.B., Poppleton, S., Owens, S., \& Kiefer T. (2008). The nature, causes and consequences of harm in emotionally-demanding occupations. London: Birkbeck College University of London for the Health and Safety Executive.

[5] Burke, R.J. (2003). Work experiences, stress and health among managerial women: Research and practice. In M.J. Schabracq, J.A.M. Winburst, C.L. Cooper (Eds.), The Handbook of Work and Health Psychology (pp.259-278). Wiltshire: John Wiley \& Sons.

[6] Chow, E.O, \& Ho, H.C. (2012). The relationship between psychological resources, social resources, and depression: results from older spousal caregivers in Hong Kong. Aging $\mathcal{E}$ Mental health, 16(8), 1016-1027.

[7] Cieślak, R., \& Widerszal - Bazyl, M. (2000). Psychospołeczne warunki pracy. Podręcznik do kwestionariusza [Psychosocial work conditions. A guide to the questionnaire]. Warszawa: Centralny Instytut Ochrony Pracy. 
[8] de Souza, J.C., de Sousa, I.C, Belísio, A.S., \& Macêdo de Azevedo, C.V. (2012). Sleep habits, daytime sleepiness and sleep quality of high school teachers. Psychology $\mathcal{E}$ Neuroscience, 5(2), 257-263.

[9] Duran A, \& Extremera, N. (2004). Self-reported emotional intelligence, burnout and engagement among staff in services for people with intellectual disabilities. Psychological Reports, 95(2), 386-392.

[10] Flueckiger, L., Lieb, R., Meyer, A.H., Witthauer, C., \& Mata, J. (2016). The importance of physical activity and sleep for affect on stressful days: Two intensive longitudinal studies. Emotion, 16(4), 488-497.

[11] Gesinde, A., \& Adejumo, G. (2012). Effects of Age and Work Experience on Job Satisfaction of Primary School Teachers: Implications for Career Counseling. International Journal of Asian Social Science, 2(3), 302-309.

[12] Glise, K, Ahlborg, G, \& Jonsdottir, I.H. (2014). Prevalence and course of somatic symptoms in patients with stress-related exhaustion: does sex or age matter. BMC Psychiatry, 14, 118.

[13] Granosik, M., Gulczyńska, A., Szczepanik, R. (2015). Transforming social atmosphere of educational centres for socially maladjusted teenagers (MOS and MOW), i.e. on the need of professional discourse development and empowering actions. Retrieved June 10, 2018 from http://dspace. uni.lodz.pl:8080/xmlui/bitstream/handle/11089/12550/2-013_046-Granosik\%2C\%20 Gulczy\%C5\%84ska\%2C\%20Szczepanik\%20\%28ang.\%29.pdf?sequence=2\&isAllowed=y

[14] Grant L., \& Kinman G. (2015). Emotional Resilience in the Helping Professions and how it can be Enhanced. Health and Social Care Education, 3(1), 23-34.

[15] Hakanen, J.J., Bakker, A.B., \& Schaufeli, W.B. (2006). Burnout and work engagement among teachers. Journal of School Psychology, 43(6), 495-513.

[16] Jenaro, C., Flores, N., \& Arias, B. (2007). Burnout and coping in human service practitioners. Professional Psychology: Research and Practice, 38(1), 80-87.

[17] Juczyński, Z., \& Ogińska-Bulik, N. (2009). Narzędzia Pomiaru w Psychologii Zdrowia [Measurement Tools in Health Psychology]. Warszawa: Pracownia Testów Psychologicznych Polskiego Towarzystwa Psychologicznego.

[18] Karłyk-Ćwik, A. (2009). Kompetencje zawodowe pedagogów w pracy z nieletnimi agresorami [Professional competences of pedagogues in work with juvenile aggressors]. Torun: W.E. Akapit.

[19] Kirkcaldy, B., \& Shephard, R.J. (2001). Occupational stress, work satisfaction and health among the helping professions. European Review Of Applied Psychology, 51(4), 243-253.

[20] Korur, E.N. (2018). The relationship between preservice physical education teacher's academic self-efficacy and proactive personality. International Journal of Anatolia Sport Sciences, 3, 281-293.

[21] Kyriacou, C. (2001). Teacher Stress: Directions for future research. Educational Review, 53(1), 27-35.

[22] Kyriacou, Ch, \& Sutcliffe J. (1977). Teacher Stress: a review. Educational Review, 29, 299-306.

[23] Lennon, M.C. (1995). Work conditions as explanations for the relation between socioeconomic status, gender, and psychological disorders. Epidemiologic Reviews, 17, 120-127.

[24] Maslach, C., \& Leiter, M. P. (1997). The truth about burnout: How organizations cause personal stress and what to do about it. San Francisco, CA, US: Jossey-Bass.

[25] Morrison, T. (2007). Emotional Intelligence, emotion and social work: context, characteristics, complications and contribution. The British Journal of Social Work, 37(2),245-263.

[26] Nutt, D., Wilson, S., \& Paterson, L. (2008). Sleep disorders as a core symptoms of depression. Dialogues in Clinical Neuroscience, 10(3), 329-336.

[27] Parent-Thirion, A., Fernández-Macías, M., Hurley, J., Vermeylen G. (2007). Fourth European Working Conditions. Dublin: European Foundation for the Improvement of Living and Working Conditions. Retrieved June 24, 2018, from htps://www.eurofound.europa.eu/ sites/default/files/ef_files/pubdocs/2006/98/en/2/ef0698en.pdf.

[28] Ratliff, N. (1988). Stress and Burnout in the Helping Professions. Social Casework, 69, 147-54.

[29] Reece-Peters, C. (2013). Teachers' issues: A case for mental health. Retrieved from http http:// uwispace.sta.uwi.edu/dspace/handle/2139/15697.

[30] Seidman, S.A, \& Zager, J. (1991). A study of coping behaviors and teacher burnout. Work $\mathcal{E}$ Stress, 5, 205-216. 
[31] Schwarzer, R., \& Hallum, S. (2008). Perceived teacher self-efficacy as a predictor of job stress and burnout: Mediation analyses. Applied Psychology: An International Review. Special Issue: Health and Well-Being, 57, 152-171.

[32] Seidman, S.A., \& Zager, J. (1991). A study of coping behaviors and teacher burnout. Work $\mathcal{E}$ $\mathcal{E}$ Stress, 5, 205-216.

[33] Szczepanik, R. (2008). Płeć jako zmienna różnicująca orzeczenie stopnia demoralizacji nieletnich dziewcząt i chłopców [Gender as a variable differentiating the verdict of the degree of demoralization of juvenile girls and boys]. In M. Chomczyńska-Rubacha (Ed.), Role płciowe, socjalizacja a rozwój [Gender roles, socialization and development] (pp. 161-172). Łódź: Wydawnictwo Wyższej Szkoły Humanistyczno-Ekonomicznej w Łodzi.

[34] Terelak, J.F., \& Mystkowski, M. (2010). Optymizm a wypalenie zawodowe u nauczycieli [Optimism and burnout in teachers]. Studia Psychologica UKSW, 10, 153-178.

[35] Williams, R.B. , Barefoot, J.C., Blumenthal, J.A., Helms, M.J., Luecken, L., \& Pieper, C.F. (1997). Psychosocial correlates of job strain in a sample of working women. Archives of General Psychiatry, 54(6), 543-548.

[36] Woolfolk, A.E., Hoy, A., \& Davis, H.A. (2006). Teachers' self-efficacy and its influence on the achievement of adolescents. In F. Pajares, T. Urdan (Eds), Self-efficacy beliefs of adolescents (pp. 117-137). Greenwich, CT: Information Age Publishing.

[37] Woolfolk, A.E., \& Hoy, W.K. (1990). Prospective teachers' sense of efficacy and beliefs about control. Journal of Educational Psychology, 82, 81-91.

[38] Yagil, D. (2012). The mediating role of engagement and burnout in the relationship between employees' emotion regulation strategies and customer outcomes, European Journal of Work and Organizational Psychology, 21, 1, 150-16. 